\title{
Effects of Food Trade Liberalization on Poverty and Inequality in Bangladesh: A Partial Equilibrium Approach
}

\author{
Mohammad Mahbubur Rahman ${ }^{1, ~ *, ~ C h e n g ~ F a n g ~}{ }^{2}$ \\ ${ }^{1}$ School of Health Sciences and Social Works, University of Portsmouth, UK \\ ${ }^{2}$ Food and Agriculture Organization of the United Nations, Rome, Italy
}

Email address:

mohammad.rahman@port.ac.uk (M. M. Rahman)

${ }^{*}$ Corresponding author

\section{To cite this article:}

Mohammad Mahbubur Rahman, Cheng Fang. Effects of Food Trade Liberalization on Poverty and Inequality in Bangladesh: A Partial Equilibrium Approach. Journal of World Economic Research. Vol. 9, No. 1, 2020, pp. 10-19. doi: 10.11648/j.jwer.20200901.12

Received: October 3, 2019; Accepted: November 12, 2019; Published: January 6, 2020

\begin{abstract}
Using a partial equilibrium model, we examine the effects of full tariffs withdrawal from food imports of Bangladesh on its poverty and inequality. We show that if tariffs are withdrawn from food imports, domestic food prices decrease, but the sizes of decreases in prices depend on import demand elasticities. Then we show that decreases in domestic prices affect households' welfare or income in three channels. As consumers of food items, households gain real income/welfare as their food expenditures reduce. As laborers in the agriculture or food processing sector, households' members may lose their income, as according to the Stolper-Samuelson theorem, changes in output prices may affect input prices positively. As sellers of food items, households lose their income. From Household Income and Expenditure Survey 2010, we find that the average effect of full tariffs withdrawal from food imports on households' welfare is positive, as all households are consumers, but all are not laborers and sellers. So, the first channel is stronger than other channels. We have found that food trade liberalization reduces the poverty rate by 2.4 percentage points. However, the main food in Bangladesh is rice, which had no import tariff in our data period. We also produce results for rice trade liberalization. If the rice tariff were the highest ever (e.g., 19.4\%) and the government reduced it to zero, the poverty rate would have decreased by 1.74 percentage points. Rice trade liberalization also reduces inequality, but trade liberalization of other foods does not influence inequality.
\end{abstract}

Keywords: Trade Liberalization, Poverty, Inequality, Partial Equilibrium

\section{Introduction}

In recent years, many researchers have been interested in showing the relationship between globalization and inequality or poverty. Trade liberalization, which means a reduction in tariffs or non-tariff barriers both at home and abroad, is an essential part of globalization. It changes consumer and producer prices, which in turn change household production, consumption, labor earnings, and transfers. In other words, trade liberalization causes income to be redistributed among people. That redistribution can go in favor of or against poor people. As poor and rich consume different items, and their income sources are also different, trade liberalization affects them in different ways.

There are several studies, which identified the effects of trade liberalization on poverty and inequality in several countries. In Bangladesh, there are a few studies [1-4], which have got mixed results of the effects of trade liberalization on poverty and inequality. The study [1] found that the poverty rate declined due to trade liberalization. The study [2] found positive effects of trade liberalization in manufacturing sectors on wage inequality estimated using the Theil inequality index. There is little evidence of increasing inequality due to trade liberalization [3]. In the short-run (long-run), because of trade liberalization, poverty rates increased (decreased) by 0.92 (4.83) percentage points and 0.06 (4.71) percentage points in rural and urban areas, respectively [4].

Arguably it might be easy to develop a relationship between trade liberalization and inequality or poverty. Empirically, it is challenging to capture such a relationship. In general, time series models are used to capture the link. In such models, inequality or poverty rate is a dependent 
variable, and trade liberalization is the independent variable. However, there are several challenges in estimating these variables correctly. The first challenge is to determine trade liberalization accurately. In developing countries, day by day, trade protections have turned from tariffs to non-tariff barriers (NTB), which are hard to measure. In general, the sum of export and import, which is called openness, is considered as trade liberalization. However, it makes simultaneity bias, because export, import, and other covariates are determined at the same time. Several studies have used simply tariff rate as a trade liberalization variable, because many countries use both tariffs and NTB for trade protections, and they change them proportionately $[5,6]$. So, the tariff rate also reflects NTB.

Estimating income inequality is another challenge. There is a controversy in defining income inequality [7]. Most of the studies have considered relative inequality rather than absolute inequality. Besides, there is a high non-response rate among rich households in household survey data, in the case of reporting true income. The non-response rate increases if household income increases. In this way, the variance of income becomes very high compared to the true variance, and income inequality measure becomes misleading. Most of the empirical studies have estimated the ratio of wages of skilled and unskilled workers as a kind of relative income inequality measure. Because of incorrect income, it is also challenging to estimate the correct poverty rate.

Most of the studies in Bangladesh used time series models, such as the error correction model and vector autoregression (VAR) model [1-3]. However, in Bangladesh, there are no suitable time series data on poverty and inequality. Bangladesh Bureau of Statistics (BSS) estimates poverty and inequality rates every five years, using Household Income and Expenditure Survey (HIES). It is surveyed by BSS every five years. For other years, poverty and inequality rates are generated through interpolation, which is not reliable in most of the cases. Those studies also used openness or openness to GDP ratio as a trade liberalization variable, which is a weak measure. The study [4] has used a dynamic CGE microsimulation model using the social accounting matrix (SAM) estimated from HIES 2005. That study estimated oneyear poverty rates for different categories of households in HIES 2005. Tariff reduction is used as trade liberalization in that study. Although CGE models are useful for giving policy shocks on the whole economy, model coefficients in SAM are often biased as they are manipulated.

This study will fill the research gap. Time series models cannot be applied in the case of Bangladesh because, for reliable estimates of poverty and inequality, they require many years of repeated cross-section surveys, but Bangladesh has a few years of repeated cross-section data. Following the study [8], we use a partial equilibrium model, which does not require any time series data. It needs just a one-year cross-section household survey data and a one year disaggregated trade policy data (e.g., import and tariff rate by Harmonized System (HS) code 6).

In the model we use here, a household might be affected through three main channels - labor income, business income, and consumption expenditure. We use HIES 2010 to estimate labor income share from working in traded sectors, business income share from doing the business of traded items, and budget share for the consumption of traded items. As required by the model, we also use tariff data from the World Trade Organisation (WTO) and import data from the Comtrade of the United Nations (UN). To estimate percentage changes in prices due to trade liberalization (withdrawal of tariffs on food imports), we use tariff and import data.

No study in Bangladesh examined the effects of trade liberalization of food items on inequality and poverty. In existing studies, trade liberalization of both food and nonfood items was considered. This study also fills such a research gap. We check how much poverty and inequality will be affected because of the withdrawal of full tariffs from food items only. We consider those food items which are available in HIES 2010. It should be noted that more than 100 food items are available in HIES 2010. However, in Bangladesh rice is the main staple food and more than 60 percent of calorie consumption comes from rice, and most of the agriculture workers work in rice sectors, but tariff rate on its import is zero in most of the times because the government wants to maintain food security in the country. Bangladesh is a net importing country of rice. In 2010, the tariff on rice imports was zero. Therefore, it is expected that the full withdrawal of tariffs from food items will not have severe effects on poverty and inequality. However, the government sometimes impose a tariff on rice (especially Indian rice) to give protection to the local rice farmers. We also check that if there were a tariff on rice, what would have happened in poverty and inequality after the withdrawal of that tariff. For this analysis, we use the highest tariff on rice within the last 20 years.

The rest of the study is organized as follows. Section 2 discusses the conceptual framework of how trade liberalization can affect poverty and inequality, and the partial equilibrium model used here. Section3 describes the background of the Bangladesh economy and data. The results are analyzed in Section 4. Section 5 concludes the study.

\section{Methodology}

\subsection{Conceptual Framework}

There are many economic arguments/explanations of how trade liberalization affects inequality. According to the study [9], trade liberalization has raised skill premium in many developing countries. It means that returns to high skilled jobs or particular occupations that require a higher level of education have increased due to trade liberalization. The intuitive idea is that when trade protections are relaxed, firms need high skilled managers and professionals who can handle trade reforms well. Some studies did not get any evidence of the increase in the skill premium [10]. However, if there is an increase in skill premium, inequality may rise. If wages in 
low skilled jobs also increase proportionately, then inequality remains stable.

On the other hand, the most widely used model of international trade, the Heckscher-Ohlin model, says the opposite of the increase in the skill premium. According to the model, trade liberalization may instead reduce the wage gap between skilled and unskilled workers. The simple argument is that developing countries that are labor abundant countries will specialize in labor-intensive products (e.g., readymade garments), and developed countries that are capital abundant countries will specialize in capital intensive products (e.g., computers, cars). Developing countries will import capital-intensive products from developed countries. Now, if developing countries relax protections on imports of capital intensive products, prices of them will go down. Stolper-Samuelson theorem that links product prices to wages in the Hecksher-Ohlin model says that because of price falls, wages of skilled workers in these sectors will fall. Then labor mobilization will occur within sectors in developing countries. High-skilled workers who worked in capital intensive sectors will move to labor-intensive sectors where low skilled workers exist. In this way, wages of highskilled workers will go down, and wage gaps between highskilled and low-skilled workers will go down too.

According to the studies $[11,12]$, skill premium still may increase in developing countries. In general, final goods are tradable goods. If trade liberalization of these goods occurs in developing countries, developed countries may shift their productions of intermediate goods to developing countries. Higher skilled workers in developing countries will move to those sectors with higher wages because of higher capital intensity in those sectors. According to the study [13], skillbiased technological change may occur in developing countries. The reason is that after trade reforms, laborintensive sectors in these countries will invest money for research and development so that they can stay in the market. Besides, trade reforms may induce firms in developing countries to upgrade the quality of their products [14]. To upgrade their products, they require high-skilled workers. In these ways, skill premiums may increase, and then inequality may increase.

In many developing countries, the informal sector occupies more than $50 \%$ of the labor force. An expansion of the informal sector is another reason for wage inequality. Because of trade liberalization, import-competing firms cut their cost, and replace regular labors with temporary ones from the informal sector. Sometimes, they use informal firms for their productions through outsourcing. Besides, they may lay off some workers who go to the informal sector. In this sector, labor regulations are weak, and the wage rate is substantially low.

When there are many studies on the relationship between trade liberalization and inequality, there is no significant study about the relationship between trade liberalization and poverty. The intuitive reason might be that relative poverty has a similar measure of relative inequality. Absolute poverty seems not the right measure of poverty in one's mind.
Partial equilibrium studies [15-21] said that trade liberalization affects both inequality and poverty through not only affecting labor income but also affecting business income and consumption expenditure. Trade liberalization changes domestic prices of imported items first, and changes in prices can affect real income for a household in three main ways - labor income (when members of a household work in sectors of imported items), business income (when members of a household do business of imported items), and consumption expenditure (when members of a household consume imported items). General equilibrium studies such as computable general equilibrium (CGE) models [4] and Global Trade and Analysis Project (GTAP) models use more channels to capture the effects of trade liberalization on poverty and inequality [22].

When one considers the relationship between trade liberalization and inequality or poverty, then short- or medium-run effects of trade liberalization on inequality and poverty come into the mind. Long-run effects are difficult to measure because trade liberalization is not a one-stop process. In general, a government gradually revises its trade policies, and it is difficult to find which trade policy affects inequality and poverty in the long-run. However, dynamic CGE and GTAP models estimate the long-run effects of trade liberalization.

\subsection{The Model}

We start with a partial equilibrium model, which was initiated by studies of Deaton $[15,16]$ and was extended by other studies [17-21]. In this model, the welfare of household $h$ is represented by an indirect utility function, $V_{h}$ :

$$
V_{h}=V_{h}\left(y_{h}, \mathrm{P}\right) \text {, }
$$

where $y_{h}$ is household income and $\mathrm{P}$ is a price vector of traded goods. $y_{h}$ is defined as:

$$
y_{h}=w L_{h}+\sum_{h} \pi_{h, g}(\mathrm{P})+G_{h}+\emptyset_{h} T,
$$

where $w$ is the wage rate; $L_{h}$ is the (net) amount of labor sold in the market by household $h ; \pi_{h, g}$ is the profit obtained from selling good $g$ in the market; $G_{h}$ are government transfers to household $h$ not associated with tariff revenue; $\emptyset_{h}$ is the share of tariff revenue redistributed to household $h$; and $T=\sum_{g} t_{g} p_{g}^{*} m_{g}$ (where $t_{g}$ is tariff rate on imports of good $g$; $p_{g}^{*}$ is the international price of the $\operatorname{good} g ; m_{g}$ is the amount of imports of good $g$ ) is the tariff revenue collected over all goods in $g$.

To see how price changes due to trade liberalization affect household welfare $\left(V_{h}\right)$, we need to optimize the indirect utility function with respect to price changes. However, for empirical analysis, we cannot estimate changes in $V_{h}$, rather the literature has captured a change in real household income, $d y_{h}$ (as a measure of welfare change), due to a percentage change in the price of a traded good, $d \ln p_{g}$. The study [21] has derived the following equation from equations (1) and (2): 


$$
d y_{h}=\sum_{g}-s_{h, g} d \ln p_{g}+\sum_{g} \theta_{h}^{w} \varepsilon_{w p_{g}} d \ln p_{g}+\sum_{g} \theta_{h}^{g} d \ln p_{g}+\sum_{g} \alpha_{g}
$$

where $s_{h, g}$ is the share of total expenditure of household $h$ spent on consumption bundle $g ; \theta_{h}^{w}$ is the share of total income of household $h$ received from working in traded good sector $g ; \varepsilon_{w p_{g}}$ is the wage-price elasticity in sector $g ; \theta_{h}^{g}$ is the share of total income of household $h$ received from selling traded good $g$; and $\alpha_{g}$ is the percentage change in government transfer (which is assumed as common to every household).

Now, to see inequality pattern due to change in the price of traded good $g$, we take the difference of average changes in household income between top and bottom income deciles. We consider $E\left[d y_{h} \mid Q_{h}=d_{r}\right]-E\left[d y_{h} \mid Q_{h}=d_{p}\right]$, where $Q_{h}$ is the quintile where household $h$ belongs to, $d_{r}$ is the top income deciles, and $d_{p}$ is the bottom income deciles. For estimating poverty rate changes as an effect of trade liberalization, we estimate poverty rates using pre-trade liberalization income $\left(y_{h}\right)$ and post-trade liberalization income $\left(y_{h}+d y_{h}\right)$.

It should be noted that after estimating $d y_{h}$ for every household, we can estimate the predicted value of it against per capita household income, $E\left[d y_{h} \mid p c e\right]$, where $p c e$ is the per capita household income. We can estimate $E\left[d y_{h} \mid p c e\right]$ by running non-parametric regression of $d y_{h}$ on pce. From $E\left[d y_{h} \mid p c e\right]$, we can then estimate $E\left[d y_{h} \mid Q_{h}=d_{r}\right]-$ $E\left[d y_{h} \mid Q_{h}=d_{p}\right]$.

However, our main challenge is to estimate $d y_{h}$ using equation (3). First of all, we have to estimate $d \ln p_{g}$. To estimate it, the study [23] has used tariff trade restrictiveness index (TTRI), which is as follows:

$$
\operatorname{TTRI}_{g}=\sum_{x, n \varepsilon g} t_{x, n} \frac{m_{x, n} \eta_{n}}{\sum_{x, n \varepsilon g} m_{x, n} \eta_{n}}
$$

where $g$ denotes the composite good which includes a subset of goods $n$ at the HS- 6 digit level, and $x$ represents the exporting partner country from which Bangladesh is importing; $t_{x, n}$ denotes the tariff rate that Bangladesh imposes on imports of good $n$ from the exporting country $x ; m_{x, n}$ is the import of good $n$ of Bangladesh from country $x$; and $\eta_{n}$ is the import demand elasticity of good $n$ in Bangladesh.

TTRI is basically the weighted average tariff on imports of good $g$ where $\frac{m_{x, n} \eta_{n}}{\sum x, n \varepsilon g m_{x, n} \eta_{n}}$ is the weight, which is difficult to estimate. In our survey data, HIES 2010, most of the cases there is no sub item $n$ under composite $g$. For example, a specific fish, say Hilsha fish, does not have any sub item, or a specific fruit, say orange, does not have any sub item. Therefore, we consider unweighted average tariffs (available in WTO) as TTRI.

From TTRI, $d \ln p_{g}\left(=\Delta \ln p_{g}\right)$ is estimated in the following way:

$$
\Delta \ln p_{g}=\frac{\Delta T T R I_{g}}{1+T T R I_{g}}=\frac{-T T R I_{g}}{1+T T R I_{g}}
$$

where the last equality follows from the assumption of full elimination of tariffs on imports of food items.
After estimating $d \ln p_{g}$, we then estimate $s_{h, g}, \theta_{h}^{w}$ and $\theta_{h}^{g}$ in equation (3) from HIES 2010. We estimate $\varepsilon_{w p_{g}}$ following the study [23], which has considered the following OLS regression equation:

$$
s_{g, t}=\frac{I_{g, t}}{G D P_{t}}=a_{g}+c_{g} * \ln L_{t}+e_{g, t},
$$

where $s_{g, t}$ is the imports-GDP ratio of item $g$ at time $t$; $a_{g}$ and $c_{g}$ are regression parameters of item $g ; \ln L_{t}$ is the $\log$ of labor endowment/force at time $t$; and $e_{g, t}$ is the error term. These then estimate $\varepsilon_{w p_{g}}$ as follows:

$$
\varepsilon_{w p_{g}}=\frac{c_{g}}{c_{l}}+s_{g}
$$

where $c_{g}$ (which captures the Rybczynski effect of changes in labor endowment on imports-GDP ratio of $g$ ) comes from regression equation (5); $c_{l}$ is the share of labor income in GDP in a specific year; and $s_{g}$ is the imports-GDP ratio of item $g$ in a specific year. We estimate $c_{l}$ and $s_{g}$ for the year, 2010. $c_{g}$ and $s_{g}$ vary by item $g$, but $c_{l}$ remains same for every item.

It should be noted that, for simplicity, we make $\alpha_{g}$ as zero as it is common to every household. The value of $\alpha_{g}$ does not matter for inequality and poverty measures.

\section{Background and Data}

\subsection{Background of the Bangladesh Economy}

Despite the global financial crisis in 2007, Bangladesh has been maintaining the GDP growth rate at around 6 percent since then. Most of the time, GDP growth crossed 6 percent. For example, the GDP growth rate stood at 6.71 percent in FY 2010-11, which was higher than 6.07 percent in FY 200910, 5.74 in 2008-09, and 6.19 in 2007-08 (see BBS). However, millions of Bangladeshi people are still poor. According to HIES 2010 conducted by BBS, 31.5 percent of Bangladeshis are living below the upper poverty lines. It should be noted that there are 16 region-wise poverty lines. On the other hand, inequality is not falling significantly; rather, it has increased some times. This is concerning as it badly affects the poverty situation of the poor. The poor people are also suffering from a high level of food inflation. In this situation, the government has introduced new export and import policies (2009-2012) to increase exports at the time of the global economic recession. The government has also been reducing import tariff rates since FY1991-92, in order to facilitate mainly export sectors where raw materials come through imports. Because of these policies, exports have increased substantially; as a result, the government has been able to maintain the GDP growth rate at around 6 percent. After this brief review, we discuss trade (of mainly food items), poverty, inequality and employment, and wages a little more elaborately as follows. 


\subsubsection{Trade of Food}

Bangladesh has switched from a highly restrictive to a considerably liberalized economy over the last three decades. Although some para-tariffs have increased in recent years, the average tariff has fallen significantly since 1990. For example, the unweighted average import tariff rate has declined from $57.22 \%$ in FY 1991-92 to $14.83 \%$ in FY2011-12. To improve trade and then economic growth, the Bangladesh government has reformed trade policy, including a substantial scaling down and rationalization of tariffs, removal of trade-related quantitative restrictions, elimination of import licensing, a unification of exchange rates, and move to a managed float exchange rate system. Upgrading import, export, and tariff policies to promote export-led growth is an important element of consistent trade policy in Bangladesh.

The overall trade volume is increasing, but the share of food in it is not increasing, rather it is decreasing. The total import payments (export earnings) increased from US $\$ 33,657$ (US \$21,000) million in FY 2010-11 to US \$35,516 (US \$22,824) million in FY 2011-12. The share of food in total imports (exports) is around 20\% (7\%) in both years. However, import, export, and tariff policies for food have designed to mitigate food insecurity. The tariff rate is kept zero on imports of the main staple food, rice (see Table 1), as about $60 \%$ of total calories, an individual consumes in a day, come from rice (for poor, it is above 70\%) (see HIES). Every political government wants to keep its price low so that people (especially poor people) can fulfill their calorie requirements from this cheap food.

Although rice production has increased substantially because of a green revolution, Bangladesh is still a net importer of rice (See Table 1, where imports of rice are much higher than exports of rice). This is another reason for keeping tariff on its imports zero. The average import tariff on soya-bean oil is also zero, as both poor and non-poor use it in everyday cooking. Besides, Bangladesh produces a little amount of it; almost the whole amount of soya-bean oil demand is fulfilled from imports. Pulses (mainly lentils) are also regularly consumed mainly by poor people, and the average import tariff on them is low (5\% in Table 1). Compared to rice and soya bean oil, it is slightly high, as Bangladesh is a net exporter of pulses (Bangladesh is sufficient in pulses).

Fishes are also consumed by both poor and non-poor people almost regularly. Poor people eat mainly aquaculture fishes (which are cheap) and inland water fishes (which are easy and sometimes free to catch). Bangladesh imports mainly marine fishes, which are expensive, and mainly rich people consume those. As a result, the average import tariff is high on fish imports. Similarly, although vegetables are regular items in consumption of poor, the average import tariff on them is high (25\% in Table 1), because generally poor people do not consume imported verities of vegetables. Spices also have a high average import tariff, because, in spite of tariffs, prices of some Indian verities are lower than Bangladeshi items. Other foods (egg, meat, milk, fruits, etc.) are mainly consumed by rich people. Import tariffs are also high on them.

Thus, we may expect the low effects of a food trade liberalization on poverty and inequality. However, we need to estimate the effects of a food trade liberalization on poverty and inequality. Such estimation will provide important knowledge in revising tariffs on food items. On the other hand, the government sometimes impose import tariffs on rice as a way of protecting rice farmers' earnings. We also examine here that if there were a tariff on rice, how much poverty and inequality would have been changed after the withdrawal of such tariff. For this examination, we take the highest tariff imposed on rice ever.

Table 1. MFN applied (average) tariffs on different food categories in HIES 2010 along with their imports and exports in 2010.

\begin{tabular}{llll}
\hline Food Item & MFN applied tariff (\%) & Imports (USD) & Exports (USD) \\
\hline Rice/Paddy & 0.0 & $332,297,610$ & $1,785,820$ \\
Pulses (e.g. lentil) & 5.0 & 710 & $124,185,169$ \\
Fish & 25.0 & $6,208,432$ & $510,202,357$ \\
Egg & 25.0 & 341,783 & 0 \\
Meat & 25.0 & 446,659 & 124,083 \\
Vegetables & 25.0 & $46,001,561$ & $44,947,967$ \\
Milk & 25.0 & $174,535,665$ & 175,352 \\
Sweet (e.g. sugar) & 25.0 & $732,776,511$ & 535,273 \\
Soya-bean Oil & 0.0 & $650,000,000$ & 243,090 \\
Mustard oil & 18.5 & 195,702 & $3,800,000$ \\
Fruits & 25.0 & $105,345,025$ & $8,499,994$ \\
Drinks (coffee, tea etc.) & 23.5 & $4,844,189$ & $3,000,000$ \\
Spices & 17.5 & $107,800,000$ & $7,838,948$ \\
\hline
\end{tabular}

Source: World Trade Organization and Comtrade of United Nations

\subsubsection{Poverty Situation}

Since 1973 Bangladesh has been implementing a five-year plan with the main focus on poverty alleviation, and Bangladesh has achieved a significant progress in it. Within just ten years, the poverty rate has declined by 18 percentage points. According to HIES 2010, 31.5\% of Bangladeshis are living below upper poverty lines; it was $40.4 \%$ in HIES 2005 and $48.9 \%$ in HIES 2001-02. In spite of this progress, poverty alleviation is still kept as the highest priority in all development agenda, because it is the key indicator of socioeconomic advancement. To achieve the Millennium Development Goal (MDG) by 2017, the Bangladesh government aimed to reduce the poverty rate to $15 \%$ by way of accelerating growth. 
Monthly household income, total expenditure, and food expenditure have increased at significant rates in recent years. For example, from HIES 2005 to HIES 2010, monthly household income increased at 11.87 percent rate, 11.67 percent rate and 11.50 percent rate in national, rural, and urban levels, respectively. Monthly household expenditure grew at rates of 16.52 percent, 16.14 percent, and 16.40 percent, of which food expenditure increased at 17.59 percent, 16.67 percent, and 19.20 percent in national, rural, and urban levels respectively. As expenditure growth rates are higher than income growth rates, many people (especially poor portion) are struggling to manage their normal life in recent times.

\subsubsection{Income Inequality}

Most of the economists undoubtedly believe that sustainable and equitable economic growth results in poverty reduction. However, in Bangladesh, the share of economic growth is not fair. Day by day, the gap between rich and poor has increased, and thus, the number of poor has increased too. Unequal economic growth alleviates poverty slowly, which causes slow economic growth. Poverty reduction is a challenging task without reducing inequality.

Rural, urban, and national wise Gini coefficients of income estimated from HIES data are represented in Table 2. We see that from 2000 to 2005 Gini coefficient has risen in the rural area but has remained the same in the urban area, and as a result, it has increased in the national level. From 2005 to 2010, it has slightly increased in the rural area but has largely decreased in the urban area, which forces Gini coefficient in the national level to fall. However, from 2000 to 2010, it has increased in the rural area and thus in the national level.

Table 2. Income Inequality (Gini Coefficient) in Bangladesh.

\begin{tabular}{llll}
\hline Year & Rural & Urban & National \\
\hline 2000 & 0.393 & 0.497 & 0.451 \\
2005 & 0.428 & 0.497 & 0.467 \\
2010 & 0.430 & 0.452 & 0.458 \\
Growth rate & 0.94 & -0.91 & 0.16 \\
\hline
\end{tabular}

Source: HIES 2000, 2005 and 2010 data

\subsubsection{Employment and Wages}

Table 3. Share of Employed Labor Force (above 15 years) by Sector.

\begin{tabular}{|c|c|c|c|c|c|}
\hline Sector & $1995-96$ & 1999-00 & $2002-03$ & 2005-06 & 2010 \\
\hline Agriculture, forestry and fishery & 48.85 & 50.77 & 51.69 & 48.10 & 47.33 \\
\hline Mining \& quarrying & - & 0.51 & 0.23 & 0.21 & 0.18 \\
\hline Manufacturing & 10.06 & 9.49 & 9.71 & 10.97 & 12.34 \\
\hline Power, gas \& water & 0.29 & 0.26 & 0.23 & 0.21 & 0.18 \\
\hline Construction & 2.87 & 2.82 & 3.39 & 3.16 & 4.79 \\
\hline Trade, hotel \& restaurant & 17.24 & 15.64 & 15.34 & 16.45 & 15.47 \\
\hline Finance, business \& services & 0.57 & 1.03 & 0.68 & 1.48 & 1.84 \\
\hline Commodities \& personal services & 13.79 & 13.08 & 5.64 & 5.49 & 6.26 \\
\hline Public administration and defense & - & - & 6.32 & 5.49 & 4.24 \\
\hline Total & 100.00 & 100.00 & 100.00 & 100.00 & 100.00 \\
\hline
\end{tabular}

Source: Labor Force Survey (LFS), 1995-96, 1999-00, 2002-03, 2005-06 and 2010.

As per BBS, 56.7 million of 15 plus aged populations are currently economically active. ${ }^{1}$ Of them, 70 percents are men, and the rest are women. About half of them are engaged in agriculture (see Table 3 ).

The nominal wage rate is increasing at a significant rate. For example, from FY 2010-11 to FY 2011-12, it increased by 11.8 percent. It increased by 15.1 percent, 2.86 percent, and 6.54 percent in agriculture, fisheries, and manufacturing sectors, respectively. Nominal wage growth in agriculture is the highest because the labor supply in the rural area is decreasing significantly because of internal and international migrations. Besides, high remittances make the rural economy healthy, and as a result, rural people have a high ability to pay high wages. However, the inflation rate is near 10 percent, and thus, we can say that the growth rate of the real wage rate is low. In fisheries and manufacturing sectors,

1 Using the latest Labor Force Survey (LFS) 2010 and the latest census (both conducted by BBS), this figure was calculated. it is rather negative.

\subsection{Data Analysis}

Our main data source is the HIES, which is a repeated crosssection survey conducted by BBS in every five years. It is a nationally representative survey. In our main analysis, we use data from the last survey - HIES 2010, which surveyed around 12,000 households and their members. The other two previous surveys, HIES 2000 and 2005, which surveyed around 7,000 and 10,000 households respectively and their members, were also used in section 2. In that section, we also used data from LFS, which is also a repeated cross-section survey. LFS collected data on labor income extensively, but HIES does on household income and expenditure. In our main analysis, we take tariff data of 2010 from WTO and import data (1990-2010) from UN Comtrade. We also use GDP and labor force data (1990-2010) from the World Bank's WDI. 
Table 4. Average values of parameters in equation (3), by broad food categories in Table 1.

\begin{tabular}{|c|c|c|c|c|c|}
\hline Food Item & $\begin{array}{l}\text { Expenditure } \\
\left.\text { Share (mean } s_{h, g}\right)\end{array}$ & $\begin{array}{l}\text { Income } \\
\left.\text { Share (mean } \theta_{h}^{w}\right)\end{array}$ & $\begin{array}{l}\text { Wage-Price } \\
\text { Elasticity (mean } \varepsilon_{w p_{g}} \text { ) }\end{array}$ & $\begin{array}{l}\text { Selling } \\
\text { Share (mean } \theta_{h}^{g} \text { ) }\end{array}$ & $\begin{array}{l}\text { Price } \\
\text { Change (mean } d \ln p_{g} \text { ) }\end{array}$ \\
\hline Rice/Paddy & 0.1531 & 0.2062 & 0.0138 & 0.0410 & 0.0000 \\
\hline Pulses (e.g. lentil) & 0.0111 & 0.0066 & 0.0154 & 0.0075 & -0.0319 \\
\hline Fish & 0.0161 & 0.0032 & 0.0001 & 0.0012 & -0.1940 \\
\hline Egg & 0.0092 & 0.0000 & -0.0001 & 0.0198 & -0.2000 \\
\hline Meat & 0.0168 & 0.0036 & 0.0000 & 0.0089 & -0.2000 \\
\hline Vegetables & 0.0071 & 0.0015 & 0.0001 & 0.0042 & -0.1805 \\
\hline Sweet (e.g. sugar) & 0.0070 & 0.0000 & 0.0300 & 0.0026 & -0.2000 \\
\hline Soya-bean Oil & 0.0261 & 0.0000 & 0.0249 & 0.0072 & -0.0128 \\
\hline Mustard oil & 0.0115 & 0.0000 & -0.0001 & 0.0000 & -0.1561 \\
\hline Fruits & 0.0114 & 0.0000 & 0.0005 & 0.0000 & -0.2000 \\
\hline Drinks (coffee, tea etc.) & 0.0158 & 0.0000 & 0.0000 & 0.0000 & -0.2000 \\
\hline Spices & 0.0118 & 0.0002 & 0.0009 & 0.0020 & -0.1715 \\
\hline Total & 0.3135 & 0.2214 & & 0.1110 & \\
\hline
\end{tabular}

Source: Author's estimations using data from HIES 2010, Comtrade of UN, WTO, WDI and BBS

To estimate the change in household income $\left(d y_{h}\right)$ due to a change in tariff rates on food items, we need to estimate values of budget share $\left(s_{h, g}\right)$, income share $\left(\theta_{h}^{w}\right)$, selling share $\left(\theta_{h}^{g}\right)$, wage-price Elasticity $\left(\varepsilon_{w p_{g}}\right)$ and percentage change in price $\left(d \ln p_{g}\right)$ due to change in tariff, as they are in equation (3). Using HIES 2010, we estimate values of three parameters - budget share $\left(s_{h, g}\right)$, income share $\left(\theta_{h}^{w}\right)$ and selling share $\left(\theta_{h}^{g}\right)$, for every household and every item in the survey. On the other hand, using time series data (1990-2010) on imports from UN Comtrade and on GDP and labor force from WDI, we run the separate OLS regression (as in equation (5)) for every food item $g$ in HIES $2010 .^{2}$ We then get values of imports-GDP ratio $\left(s_{g}\right)$ and the Rybczynski effects of changes in labor endowment on imports-GDP ratio $\left(c_{g}\right)$ of 2010, and we take the value of the share of labor income in $\operatorname{GDP}\left(c_{l}\right)$ of 2010 from BBS. Thus, using equation (6) we estimate the value of wage-price elasticity $\left(\varepsilon_{w p_{g}}\right)$ for every item in HIES 2010. Using equation (4), we estimate the value of percentage change in price $\left(d \ln p_{g}\right)$ due to a change in tariff. To estimate it, we use the unweighted tariff as $T T R I_{g}$. However, $\varepsilon_{w p_{g}}$ and $d l n p_{g}$, which vary with only food items, are available with HS codes, and $s_{h, g}, \theta_{h}^{w}$ and $\theta_{h}^{g}$, which vary with household and food item, are not available with HS codes. We give relevant HS codes to food items in HIES 2010, and then merge data on $s_{h, g}, \theta_{h}^{w}$ and $\theta_{h}^{g}$ (available by household and HS code) and data on $\varepsilon_{w p_{g}}$ and $d \ln p_{g}$ (available by HS code only) by HS code.

In Table 4, average values of $s_{h, g}, \theta_{h}^{w}, \theta_{h}^{g}, \varepsilon_{w p_{g}}$ and $d \ln p_{g}$ over households and sub food items under broad food categories are represented by broad food categories. We see that budget/expenditure share is available in every broad food category, but in more than half of the broad food categories,

2To match food items in HIES 2010 with that in imports and tariff data is a difficult task. Imports and tariff data are available with HS codes. In some cases, food items under these codes do not match exactly with food items in HIES 2010. However, we have taken those HS codes in imports and tariff data that closely match with food items in HIES 2010. Although GDP and labor force do not vary with a food item, $s_{g}$ and $c_{g}$ vary with a food item as imports vary. income share is not available and in three broad food categories, selling share is also not available (because every household is a consumer, but every household is not a producer or a seller). Moreover, wage-price elasticity is extremely low (near zero) in most of the broad food items. That means that wage is inelastic with the price change. It happens as agriculture employments are seasonal or casual. There is no point for a wage cut due to the price cut. Besides, most of the landowners produce foods for mainly own consumption, and the price change in the market does not influence them to change wage. However, as every broad food category contains (the average) value of expenditure share (see table 4), this share will have the strongest influence on household income change $\left(d y_{h}\right)$, and such influence will be positive as $d \ln p_{g}$ contains negative value and there is a negative sign befores $s_{h, g}$ (see equation (3)).

Although budget share has the strongest influence on income change, half of the food budget ( 0.1531 out of 0.3135 in Table 4) goes to rice/paddy, which has zero import tariff and thus zero price change. The major income share $(0.2062$ out of 0.2214 ) comes from working in the rice sector. Selling share is the highest in the case of rice. So, the overall effect of tariff withdrawal on household income and thus poverty and inequality will be very small or insignificant.

\section{Results}

\subsection{Main Results of the Effects of Food Trade Liberalization}

Following equation (3), we have calculated income change $\left(d y_{h}\right)$ for every household. We have plotted kernel density of it in Figure 1, where the mean value of it (indicated by the vertical line) is 0.03354 or 3.354 percent, which is very low mainly because the tariff is zero on rice imports (as we have discussed before). However, this mean value is positive because all households are consumers, but all are not sellers or employees in agriculture. Because of consumption, real incomes of households are affected positively due to prices fall resulted from trade liberalization (see equation (3)). 
Although being sellers or employees, real incomes of households are affected negatively, positive effects dominate negative effects, and therefore, the average value is positive. Some households have a negative value of $d y_{h}$ as because probably their incomes come from mainly selling foods. If the share of income from selling foods in total income is very high, then positive effects are dominated by negative effects.

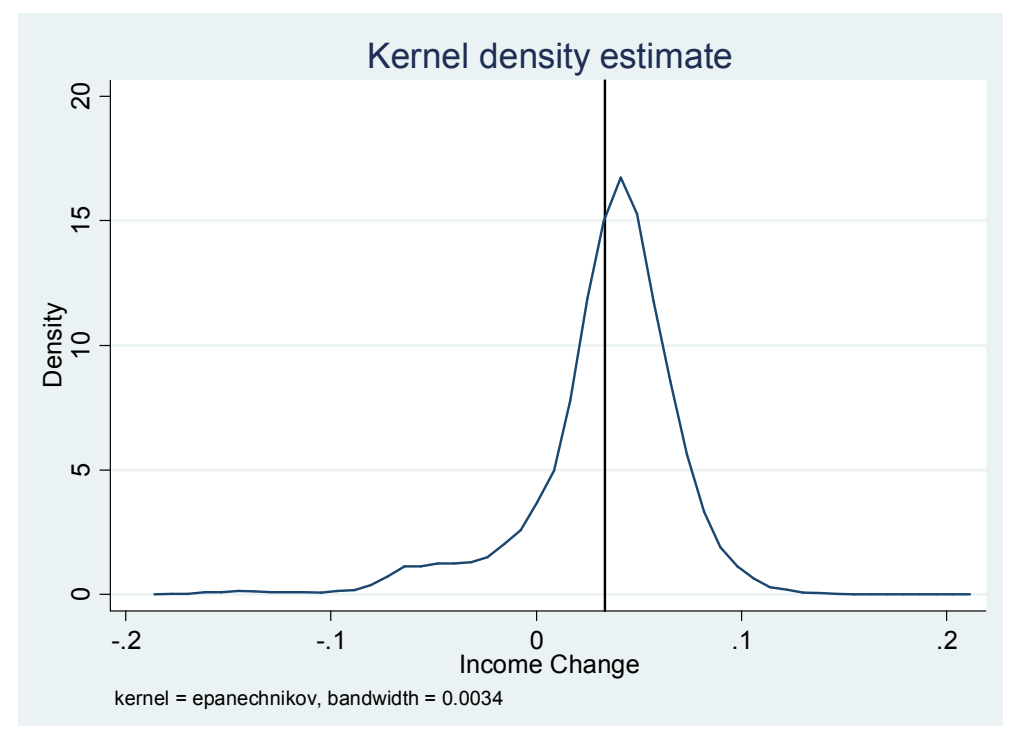

Figure 1. Plotting kernel density of income change $\left(d y_{h}\right)$.

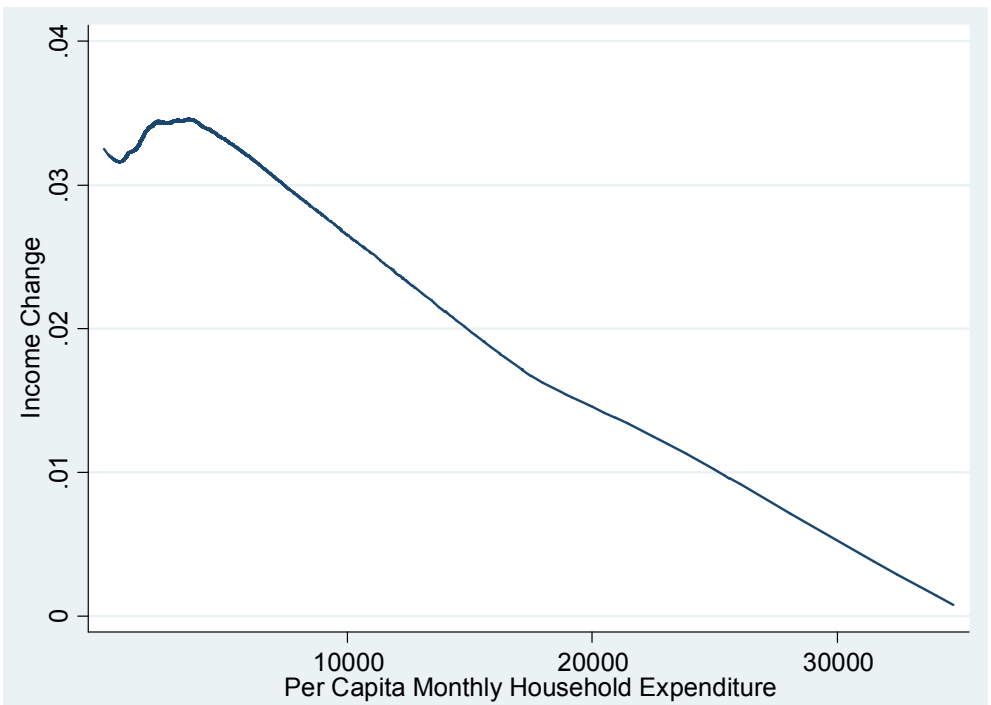

Figure 2. Non-parametric estimation of income change ( $\left[\right.$ [dy $\left.y_{h} \mid p c e\right]$ ) is plotted against per capita monthly household expenditure (pce) (Bandwidth=0.8).

Table 5. Comparison of predicted value of income change ( $\left.\left[d y_{h} \mid p c e\right]\right)$ between households below or equal to $1^{\text {st }}$ decile of pce and above or equal to $10^{\text {th }}$ decile of pce.

\begin{tabular}{llll}
\hline Group & Observation & Mean of $\boldsymbol{E}\left[\boldsymbol{d} \boldsymbol{y}_{\boldsymbol{h}} \mid \boldsymbol{p c e}\right]$ & t-ratio \\
\hline pce $\leq 1{ }^{\text {st }}$ Decile of pce $(=1097.04)$ & 1221 & 0.0320 & 4886 \\
pce $\geq 10^{\text {th }}$ Decile of pce $(=4416.786)$ & 1217 & 0.0307 & 253 \\
Combined & 2438 & 0.0313 & 506 \\
Difference & & 0.0013 & 10 \\
\hline
\end{tabular}

We have run a non-parametric regression of $d y_{h}$ on per capita monthly household expenditure (pce), and then we get the predicted value of $d y_{h}, E\left[d y_{h} \mid p c e\right]$, for every household. ${ }^{3}$ In Figure 2, we have plotted it against pce. ${ }^{4}$ We

3 In developing countries, income data has a lot of measurement error. It is difficult to get true income data. Expenditure data is a good proxy of true income data [24]. see that it is downward sloping, which indicates that trade liberalization on food imports reduces inequality, as low-

4Kernel density of pce is plotted in Figure A1 in the Appendix A. We see that the maximum value of pce is around 70,000 (with the mean value is 2518.163 shown by the vertical line), but almost all households belong below 10,000 of pce. However, to understand the overall pattern of $E\left[d y_{h} \mid p c e\right]$, we have taken pce less than 35,000 in Figure 2. 
income households have higher income change than highincome households. However, if we compare means of predicted value of income change $\left(E\left[d y_{h} \mid p c e\right]\right)$ estimated from non-parametric regression in Figure 2 between households below or equal to $1^{\text {st }}$ decile of pce and above or equal to $10^{\text {th }}$ decile of pce, in the last row of Table 5 , we see that the mean difference of $E\left[d y_{h} \mid p c e\right]$ between these two groups is $(0.0320-0.0307)$ or 0.0013 or 0.13 percentage points, which might be economically insignificant but it is statistically significant as t-ratio is around 16 .

To estimate the poverty impact of full trade liberalization, we estimate first the new pce after the trade liberalization, indicated by $p c e_{a t l}$, for every household in the following way:

$$
\text { pce } e_{\text {atl }}=p c e+p c e * d y_{h} .
$$

We then estimate two poverty rates using two per capita monthly household expenditures (without trade liberalization, pce and with trade liberalization, $\left.p c e_{\text {atl }}\right)$ and 16 region-wise upper poverty lines. Two poverty rates are 37.87 and 35.47 without and with trade liberalization, respectively. So, after food trade liberalization, the poverty rate may decrease by more than 2 percentage points. From the economic point of view, it is not a small number when we have seen zero import tariff on rice, which is the main staple food in Bangladesh.

\subsection{Results of the Effects of Liberalization of Rice Trade}

In the previous subsection, we have got results using data in 2010 when the rice has no import tariff. However, the Bangladesh government sometimes imposes a tariff on rice imports to protect rice farmers. As rice is the main staple food in Bangladesh, it is, therefore, important to know what will happen in poverty and inequality due to a full withdrawal of tariff from rice imports. We examine the effects of rice trade liberalization on poverty and inequality by reducing the tariff rate from an arbitrary number to zero. To make the examination more realistic, we choose the highest tariff rate within the last 20 years as the arbitrary tariff rate.

Within the last 20 years, the highest tariff rate on rice imports was seen in 2011 as $19.4 \%$. Now, we think that if the tariff rate were reduced from $19.4 \%$ to $0 \%$, what would have happened in poverty and inequality. To know this, we first estimate the percentage change in the price of rice $\left(\Delta \ln p_{\text {rice }}\right)$ as -0.1625 or $-16.25 \%$ due to the tariff reduction from $19.4 \%$ to $0 \%$. Using time-series data, we regress domestic price of rice on tariff rate, and thus, we estimate the price change. If we consider budget share, income share and selling share of rice in HIES 2010, and -0.1625 as a change in the price of rice and use all of them in equation (3), we can estimate the changes in poverty and inequality as the similar way as we did in the previous subsection. We find that the poverty rate reduces from $37.87 \%$ to $36.13 \%$. So, such an arbitrary trade liberalization of only rice can reduce the poverty rate by 1.74 percentage points, which is a large figure compared to the poverty effect of the trade liberalization of all other foods, which is estimated as -2.4 percentage points in the previous subsection. We can say that if there were a tariff on rice imports as $19.4 \%$ and trade liberalization of all food items occurred, the poverty rate would have reduced by more than 4 percentage points (adding 1.74 with 2.4).

As a measure of the inequality effect of such rice trade liberalization, we find that the percentage (positive) change in the overall income in the first decile of income group would have been 0.0341 or 3.41 percentage points (statistically and significantly) higher than that in the tenth decile of the income group. Compared to the inequality effect in the previous subsection (which is 0.0013 or 0.13 percentage points), this is a large number. So, the trade liberalization of rice significantly improves inequality too.

\section{Conclusion}

In this study, we examine how much full trade liberalization of food in Bangladesh affects poverty and inequality. We use a partial equilibrium model where we show that trade liberalization reduces domestic food prices first, and the sizes of decreases in prices depend on import demand elasticities. Then we show that reductions in domestic prices affect households' welfare or income in three ways. As consumers of food items, households gain real income/welfare as their food expenditures reduce. As laborers in the agriculture or food processing sector, households' members lose their income, as according to the Stolper-Samuelson theorem, changes in output prices may affect input prices positively. As sellers of food items, households lose their income. After merging trade data in 2010 with Household Income and Expenditure Survey 2010, we find that the average effect of full tariffs withdrawal from food imports on households' welfare is positive, as all households are consumers, but all are not laborers and sellers, and thus, positive effects outweigh negative effects. Thus, full removal of tariffs from food imports reduces the poverty rate by 2.4 percentage points but negligibly changes inequality.

Although in 2010 the tariff rate on rice imports was zero, the Bangladesh government sometimes imposes a tariff rate on rice imports. The highest tariff rate on rice imports was seen in 2011 as $19.4 \%$ within the last 20 years. If that rate were reduced to zero, the poverty rate would have reduced by 1.74 percentage points. Due to such rice trade liberalization, the welfare change in the bottom income group would have been 3.41 percentage points higher than that in the top income group. Thus, we see that trade liberalization of only rice can drastically improve poverty and inequality if we compare the effects of trade liberalization of all other foods except rice on poverty and inequality.

However, there are limitations in this study in the case of merging trade data and household survey data by using food items. Trade data is available in disaggregate levels of food items (e.g., HS-6 digit), while household survey data contains aggregate food category levels in most of the cases. We could not make correct matches of food items between trade data and household survey data. If we consider this issue, our results are biased. Although bias may be low, a purposeful household survey could remove such bias. 


\section{Acknowledgements}

I, Mohammad Mahbubur Rahman, would like to thank Moshiur Rahman for an excellent research assistantship. I also thank the Food and Agriculture Organization (FAO) of the United Nations for generous research funding. The FAO had no role in the design, conduct, analysis, or reporting of the study. The views expressed here do not necessarily reflect those of the FAO.

\section{Appendix}

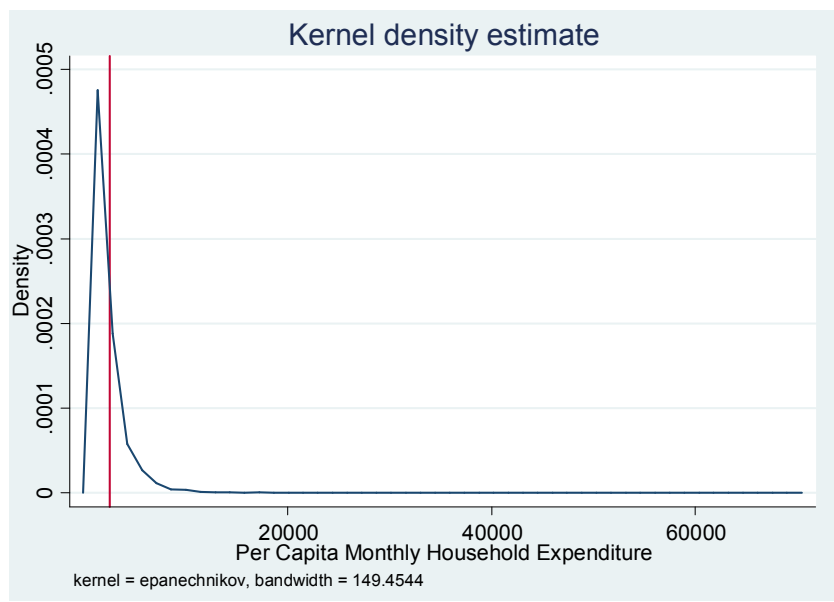

Figure A1. Plotting kernel density of per capita monthly household expenditure (pce).

\section{References}

[1] Ahmed, Sadiq and Zaidi Sattar (2004). Trade Liberalization, Growth and Poverty Reduction: The Case of Bangladesh, Washington, D. C.: World Bank.

[2] Hossain, Mohammad A. (2011). Trade Liberalisation and Wage Inequality in the Bangladesh Manufacturing Sector, 1973-1994, Bangladesh Development Studies 34 (3), 31-53.

[3] Nath, HiranyaK. and Mamun, Khawaja A. (2004). Trade liberalization, Growth and Inequality in Bangladesh: An Empirical Analysis, manuscript presented in $41^{\text {st }}$ Annual Conference of the Missouri Valley Economic Association held in Nashville, TN.

[4] Raihan, S. (2010). Welfare and poverty impacts of trade liberalization: a dynamic CGE microsimulation analysis. International journal of microsimulation, 3 (1), 123-126.

[5] Hanson, G. and A. Harrison (1999): "Trade and wage inequality in Mexico," Industrial and Labor Relations Review 52 (2), 271-288.

[6] Pavcnik, N., A. Blom, P. K. Goldberg, and N. Schady (2004). Trade Policy and Industry Wage Structure: Evidence from Brazil, World Bank Economic Review, Vol. 18 (3), pp. 319-344.

[7] Ravallion, M. (2003). The debate on globalization, poverty and inequality: why measurement matters. International Affairs, 79 (4), 739-753.
[8] Nicita, A., Olarreaga, M. And Porto, G. (2011). Pro-Poor Trade Policy in Sub-Saharan Africa, Centrode Estudios Distributivos, Laborales y Sociales.

[9] Cragg, M. I. and M. Epelbaum (1996). Why has wage dispersion grown in Mexico? Is it the incidence of reforms or the growing demand for skills?, Journal of Development Economics, Vol. 51, pp. 99-116.

[10] Attanasio, O., Goldberg P., and N. Pavcnik (2004). Trade Reforms and Wage Inequality in Colombia, Journal of Development Economics 74, 331-366.

[11] Feenstra, R. and G. Hanson (1996). Foreign Investment, outsourcing and relative wages, in R. C. Feenstraet. al. (eds). Political economy of trade policy: essays in honor of JagdishBhagwati: MIT Press, Cambridge, 89-127.

[12] Feenstra, R. C., \& Hanson, G. H. (2003). Global production sharing and rising inequality: A survey of trade and wages. Handbook of international trade, 1, 146-85.

[13] Wood, A. (1995). How Trade Hurt Unskilled Workers, Journal of Economic Perspectives, 9 (3), pp. 57-80.

[14] Melitz, M. (2003). The Impact of Trade on Intra-industry Reallocations and Aggregate Industry Productivity, Econometrica 71, 1696-1725.

[15] Deaton, A. (1989). Rice Prices and Income Distribution in Thailand: a Non-parametric Analysis, The Economic Journal, 99 (Supplement), pp. 1-37.

[16] Deaton, A. (1997). The Analysis of Household Surveys - A Microeconometric Approach to Development Policy. Baltimore: Johns Hopkins Press.

[17] Ravallion, M. (1990). Rural welfare effects of food price changes under induced wage responses: theory and evidence for Bangladesh. Oxford Economic Papers, 42 (3), 574-585.

[18] Coello, B., M. Fall and A. Suwa-Eisenmann (2011), Trade liberalization and poverty dynamics in Vietnam 2002-2006, mimeo, INRA, Paris School of Economics.

[19] Porto, G. (2006). Using Survey Data to Assess the Distributional Effects of Trade Policy, Journal of International Economics, 70, 140-160.

[20] Porto, G. (2010). International Market Access and Poverty in Argentina, Review of International Economics, May 2010.

[21] Nicita, A. (2009). The Price Effect of Trade Liberalization: Measuring the Impacts on Household welfare, Journal of Development Economics, vol. 89 (1), pp. 19-27.

[22] Ackerman, F. and Gallagher, Kevin P. (2008). The Shrinking Gains from Global Trade Liberalization in Computable General Equilibrium Models, International Journal of Political Economy 37 (1), 50-77.

[23] Nicita, A., Olarreaga, M., \& Porto, G. (2014). Pro-poor trade policy in Sub-Saharan Africa. Journal of International Economics, 92 (2), 252-265.

[24] Skoufias, E. (2003). "Is the calorie-income elasticity sensitive to price changes? Evidence from Indonesia, "World Development, 31 (7), 1291-1307. 